\title{
Brownfield Management in Greece. The Case of Piraeus
}

\section{Tousi Evgenia*}

Dr.Architect-Urban and Regional Planner NTUA, Adjunct Lecturer, University of West Attica, Department of Interior Architecture

\section{Serraos Konstantinos}

Professor, National Technical University of Athens, School of Architecture

*Corresponding author: etousi@uniwa.gr

\section{Гrossef} http://dx.doi.org/10.5755/j01.sace.27.2.25175

The article presents the contemporary condition in Greece as far as brownfield management is concerned. The analysis of the key-obstacles is illustrated through the case of Piraeus. Research includes literature review and field work. Major Piraeus' brownfield sites are classified according to international categorizations. Research findings are depicted in thematic maps, using as key-categories the former use, the current use, the system of ownership, the presense of monuments of industrial architectural heritage, the presence of archaealogical sites. This cartographic depiction functions as a necessary tool for policy making on urban regeneration. The conclusions derived from field work provide useful information for further investigation. The ultimate purpose of the article is to highlight the current challenges and potentialities, making the appropriate connections with the international experience on the field.

Keywords: Brownfields, urban regeneration, de-industrialization, Greece.

The issue of brownfield management has been attracting scientific interest since the 90s in many countries around the world. Strongly associated with the stages of the capitalistic system, brownfields have usually a central role in urban planning policies (Nebojša, 2015). Definitions offered by international literature either focus on environmental damage (EPA, 2011; HSRC, 2006) or on dereliction (Dixon, 2007 and Alker et.al., 2000). The scale of brownfield sites varies widely, from small storage facilities to factories, abandoned military bases, former quarries, sites of former extractive activities and so on. These differences on the scale of the site combined with the variety of former uses have led to methodological problems. Moreover, market driven limitations hinder further development especialy in cases that are not attractive to private investors (CPRE, 2009). Another crucial issue is the fact that many countries lack national environmental standards and cohesive legal framework. From this point of view, Greece and many other member states of the European Union, face multiple challenges on redeveloping brownfield sites, despite the existing European Guidelines.

For the European Union, the first attempt to handle the brownfield issue dates back to the mid-nineties, when Programs Urban I and II were implemented ( Pérez, et.al., 2015). These programs have been part of the overall socio-economic cohesion policies of the European Union as expressed in the Single European Act of 1987. A few years later the CLARINET (Contaminated Land Re-
Brownfield Management in Greece. The Case of Piraeus

JSACE $2 / 27$

Received 20200126

Accepted after revision 20200823

\section{Introduction}

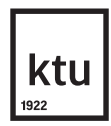

Journal of Sustainable Architecture and Civil Engineering Vol. 2 / No. 27 / 2020 pp. $5-15$

DOI 10.5755/j01.sace. 27.2.25175 
habilitation Network for Environmental Technologies in Europe) action complemented previous policies. However, many member states of the European Union follow different procedures on brownfield redevelopment. In particular, in countries like Greece, there is a lack of cohesive national framework that is able to incorporate all the different cases of brownfield rehabilitation and reuse. The national legislation on the issue is fragmental characterized by deficiency of sustainable approach. Furthermore, there are no cartographic data or other forms of digital information describing the accurate location of brownfield sites. In addition, there is no public institution with specialized jurisdiction on brownfield management. Moreover, complex administrative structures and procedures are responsible for delays in implementing environmental legislation (EU,2019). The observation of these problems was the starting point of this research which tries to portray the contemporary situation in Greece, focusing on Piraeus, as a pilot case study.

The selection of Piraeus as a case study is associated with the fact that this area hosts one of the major ports in Europe. Today, Piraeus accommodate appropriately one million visitors per year according to OECD report (OECD, 2017). It is the largest cruise port in Balkans (ibid). Apart form this, it is one of the major terminals for cargo ships after the collaboration between the Piraeus Port Authority (PPA) and the Chinese firm Cosco. The Piraeus Port Authority, established during the 30s, run multiple facilities as container handling area, car handling area, cruise shipping area, passenger shipping area and ship repair area (Chlomoudis, 2015). All these different land uses are located in the central part of the port and the peripheral municipalities that belong to the Regional Administrative area of Piraeus. In 2008, negotiations between the Chinese firm COSCO and PPA led to a 35-year contract that allows COSCO to operate Piers II and III of Piraeus Port (Van der Putten, et.al., 2016). This contract has affected the neighboring land uses, influencing the redevelopment of abandoned brownfield sites.

On account of all these, this case study highlights the significance of brownfield reuse in the era of globalization, where urban planning policies are influenced by cross-border collaborations. Piraeus port is becoming a prominent case study as a focal point for maritime transportations (Soltaniehha et.al., 2014) From this point of view, brownfield management in this area could be considered as a high priority. The main purpose of this research is to stress the importance of this issue, presenting the current challenges and potentialities.

The methods used include review of international literature and field work. Literature review focuses not only on scientific papers related to the issue but also on the pertinent Greek legislation, so as to provide a succinct overview of the legal framework. Furthermore, the research has taken into consideration three main types of categorization; BRM (Brownfield Revitalization Methodology), CABERNET classification and classification based on former use (Petrikova, 2012). The aim is to investigate in depth the regional administrative area of Piraeus in light of brownfield management.

To begin with, BRM organizes all brownfield sites into four categories based on the type of site. To the first category, named $A$, belong abandoned buildings while category $B$ consists of contaminated land with or without buildings. Category $\mathrm{C}$ comprises under-functioning buildings that have been incorporated into an urban redevelopment program. Category $D$ consists of facilities that are currently in use, characterized as suitable for redevelopment. Nonetheless, these areas have not been assigned to a statutory urban redevelopment program. On the other hand, CABERNET classification focuses on economic parameters, having three major categories. The first category named A-type sites, involves brownfield areas that attract private investors while categories $B$ and $C$, collect the less appealing brownfields to private investors. To the C-type sites, belong brownfields that have potential for redevelopment only by public funding because of their unfavorable location or their high level of contamination. The last major categorization, takes into account the former use of the site. In view of this approach, all brownfield sites are organized into the following groups (Petrikova, 2012): 
_ Former industrial areas

_ Landfills

_ Former military facilities

abandoned mining facilities

abandoned transportation facilities abandoned buildings of all uses

abandoned under construction buildings

Former agricultural facilities used for intensive farming.

On account of all these, the conducted field work in Piraeus was necessary so as to gather information for the most important brownfield sites. The criteria for the selection of the depicted brownfield sites were the location and the size of the area they cover. The aim was to organize the pieces of information according to the three previously mentioned methods. The first step was to identify the brownfields within the urban fabric of Piraeus, using the official master plan that illustrates the current land uses. Following the identification of brownfields, the next step was to gather data regarding the following categories:

_ presence of new land uses

_ property ownership

_ presence of hardcore brownfield sites

_ type of old use

_ presence of buildings characterized officially as landmarks of industrial architectural heritage

_ year of construction (for brownfield sites that include buildings)

- year of dsicontinuance of function (for brownfields that include buildings)

These data have been accumulated through queries to official public authorities as the Municipality of Piraeus and the Historic Archive of Piraeus. Moreover, field work involved multiple visits to the brownfield areas and 30 semi-constructed interviews with members of the local community, either residents or people working in the regional administrative area of Piraeus. The interviews had been collected during the period $10^{\text {th }}$ of May-30th of June of 2019. The interview guide focused on participants' perspective on the future redevelopment of the area around the port and the contribution of brownfield sites to the new masterplan. The participants shared different socio-economic attributes (educational level, sector of employment, age and gender) as presented in the tables below.

\begin{tabular}{c|c|c|c|c|c}
\hline \multicolumn{3}{|c|}{ Gender } & \multicolumn{3}{c}{ Educational Level } \\
\hline male & female & other & primary school degree & secondary degree & tertiary degree \\
\hline 13 & 17 & 0 & 3 & 17 & 10 \\
\hline
\end{tabular}

\begin{tabular}{c|c|c|c|c|c|c|c|c}
\hline \multicolumn{4}{c|}{ Age (years) } & \multicolumn{4}{c}{ Years living or/and working in Piraeus } \\
\hline $20-35$ & $36-45$ & $45-55$ & $55-67$ & more than 67 & $1-5$ & $6-15$ & $16-25$ & more than 25 \\
\hline 10 & 4 & 6 & 3 & 7 & 6 & 4 & 9 & 11 \\
\hline
\end{tabular}

\begin{tabular}{c|c|c|c|c}
\hline \multicolumn{5}{|c}{ Type of employment } \\
\hline \multirow{2}{*}{ self employed } & employee & retired & unemployed & student/part time worker \\
\hline 6 & 5 & 8 & 6 & 5 \\
\hline
\end{tabular}

\section{Table 1}

Socio-economic attributes of the participants in the qualitative research (gender and educational level)

\section{Table 2}

Socio-economic attributes of the participants in the qualitative research, age and years living or/and working in Piraeus

\section{Table 3}

Socio-economic attributes of the participants in the qualitative research, type of employment 


\section{Results}

\section{Brief Overview of the Greek Legislation on Brownfields and the Case of Piraeus}

These participants were chosen using the method of purposeful random sampling so as to increase credibility. The qualitative research was vital so as to comprehend the emerging tedencies among the members of the local community as far as brownfield redevelopment is concerned, taking into account the suggested new land uses around the port. The information gathered from the interviews combined with the cartographic data is able to offer useful evidence so as to outline the major key-obstacles that hinder sustainable urban development.

Research results follow three directions, as presented in the following chapters. First and foremost, the analysis of the pertinent legal framework, reveals the fragmentary character of the current legislation, while the description of the physiognomy of brownfield land in an area of strategic interest as Piraeus, portrays the significance of the issue. Finally, the classification of brownfields in Piraeus according to the three international methods, provides a well documented approach, organizing and categorizing different cases of brownfield land. Research findings are illustrated in thematic maps as the first step of an overall cartographic depiction of brownfields at local and regional level. These maps could function as a useful tool so as to monitor future development in the area, by recording all new land uses located on former brownfield sites. Moreover, mapping of different variables affecting brownfield areas could offer a well rounded perspective on the contemporary problems and conflicts that urban planning should resolve. Research also presents local community's concerns on the new patterns of urban development around Piraeus port owed to the presence of foreign investors.

According to the Environmental Implementation Review of the European Union (2017), Greece faces numerous challenges in the field of environmental protection (EU, 2019). One major issue is associated with the closure of illegal landfills combined with the treatment of hazardous wastes. Another target regards the implementation of the Urban Waste Water Treatment Directive of the EU. Based on EU's review, Greece should establish an efficient national environmental protection system, able to raise awareness. In addition, it is necessary to create the right incentives for sustainable investments. At national level, the environmental specifications for cleaning contaminated land are described in Chapter 7 of the law KYA 24944/1159/06. Despite the fact that allusion has been made in a variety of statutory acts, there is no specialized legal framework regarding soil protection. Standards for relative field studies are presented in law KYA 24944/1159/2006. Various scattered excerpts concerning brownfields are found in laws referring to soil and water protection as presented in the following table (Table 4). This fragmental legal framework is considered as one of the key-obstacles that hinder further development.

Apart from the above mentioned laws, it is important to summarize the legislation referring to former military facilities, as presented in the table (Table 5). Former military facilities are considered to be important brownfield sites, able to redevelop for the benefit of the local communities. Such brownfields could be found in the urban agglomeration of metropolitan areas as in the case of Thessaloniki.

It is important to mention that the concept of "strategic investment" was introduced in the Greek legislation with the law N3894/2010. This law focused on the exploitation of public property. These strategic investments are inaugurating the new era of transnational collaborations. These collaborations often conclude to the construction of flagship projects located in areas of strategic interest. Piraeus offers opportunities for redevelopment because of the presence of brownfield sites. In particular, the zone around the port attracts private local and foreign investors, especially the last ten years.

As for the legal framework influencing brownfield management in Piraeus, besides the above mentioned, the "Attica Regulatory Plan" of 2014 and the local General Urban Plan play a predominant role. On the one hand "Attica Regulatory Plan" highlights the supralocal significance of Piraeus Port and on the other local Urban Plan defines land uses and facilities. On account of the fact that the new 


\begin{tabular}{c|c|c}
\hline law & year & \multicolumn{1}{c}{ Short description } \\
\hline N1650 & 1986 & a general law for Environmental Protection \\
\hline KYA 80568/4225 & $19987 / 553$ & $\begin{array}{l}\text { Measures and restrictions for the protection of underground water } \\
\text { from polluted substances }\end{array}$ \\
\hline KYA 114218 & 1997 & $\begin{array}{l}\text { Methods and restrictions for using silt coming from urban effluent } \\
\text { for agricultural purposes }\end{array}$ \\
\hline KYA 50910/2727 & 2003 & $\begin{array}{l}\text { Measures and conditions for soil waste management. National and } \\
\text { Regional management planning. }\end{array}$ \\
\hline KYA 13588/725 & 2006 & $\begin{array}{l}\text { Measures and restrictions for dangerous waste complying with the } \\
\text { European Guideline 91/689/EOK }\end{array}$ \\
\hline KYA 24944/1159 & 2006 & $\begin{array}{l}\text { Replacement of number 19396/1546/1997 ministerial decision } \\
\text { Approval of General Technical Standards for Hazardous Waste Man- } \\
\text { agement, according to the article 5 (paragraph B) KYA 13588/725, } \\
\text { complying with European Guideline number 91/15 6/ EK }\end{array}$ \\
\hline
\end{tabular}

\begin{tabular}{l|l|l}
\hline law & year & \multicolumn{1}{c}{ Short description } \\
\hline N1337 & 1983 & $\begin{array}{l}\text { Establishment of Urban Reorganization Enterprise (in Greek-EPA), } \\
\text { Assignation of former military land property to the local Munici- } \\
\text { palities }\end{array}$ \\
\hline N2745 & 1999 & $\begin{array}{l}\text { Reorganization of former military land-renewal of assigned for- } \\
\text { mer military bases/procedure of urban planning and design }\end{array}$ \\
\hline N3883 & 2002 & $\begin{array}{l}\text { Economic resources coming from the exploitation of the military } \\
\text { property attributed to the redevelopment of the site }\end{array}$ \\
\hline N4407 & 2010 & Assignation of military property to public authorities \\
\hline \multirow{2}{*}{2016} & $\begin{array}{l}\text { Article 16: exploitation of abandoned military facilities in the con- } \\
\text { text of strategic planning }\end{array}$ \\
\hline
\end{tabular}

Regulatory Plan emphasizes on limiting urban sprawl (Kaltsa, 2015), brownfield redevelopment could be perceived as a necessary tool so as to achieve resielience and sustainability in terms of urban planning. Moreover, the geopolitical position of the port and the recent cross-border collaborations have altered the land uses around it affecting brownfield areas as well. These new land uses are associated with the new type of development met during the last years because of the thirty-five year lease between the local authorities and the Chinese Firm Cosco. As presented in the next chapter, cruise ship terminals, luxury hotels and related land uses are to be located around the port transforming the character of the existing urban fabric.

Since the early antiquity, Piraeus Port had an important geopolitical position. However, the sequence of historical events had driven the area to desolation and depopulation. The city had been mostly deserted throughout the Ottoman occupation of Greece. After the liberation of Greece from the Ottoman Regime and the nomination of Athens as the new capital, Piraeus gradually regained its power and significance, constituting the base for the industrial development of the capital of Greece. In the dawn of the 19th century, the area attracted internal migrants

\section{Physiognomy of Brownfield Land in Piraeus}

Greek Legislation related to brownfield land, authors' categorization

\section{Table 5}

Greek Legislation concerning former military facilities, authors' categorization 
that used to work either at the local factories or in the sector of constructions (Leontidou,1989). The refugee inflow subsequent to the Asia Minor Catastrophe in 1922, brought more than 40.000 refugees at Piraeus port (Pentzopoulos,1962). The urban refugee settlements had been constructed outside the boundaries of the urban agglomeration of Piraeus in a distance of 3 to 4 kilometers (Sarigiannis, 2000). Next to them industrial units had been located. Under the pressure of the refugee issue, Piraeus was gradually forming its industrial physiognomy (see map 6). The period of prosperity covered more than three decades until the late eighties, when the sector of industry experienced an unprecedented downfall (see map 7). Until the mid-nineties the majority of factories had stopped functioning, creating large brownfield areas around the port or along the major transportation roads (see map 8). The main type of brownfields, according to the former use, is abandoned industrial facilities but there are also scattered enclaves of derelict buildings in the post-refugee urban neighborhoods of Piraeus (see map 9).

\section{Fig. 6,7}

Year of construction and year of discontinuance of function, authors' work

\section{Fig. 8, 9}

Landmark industrial buildings and type of old use, authors' work
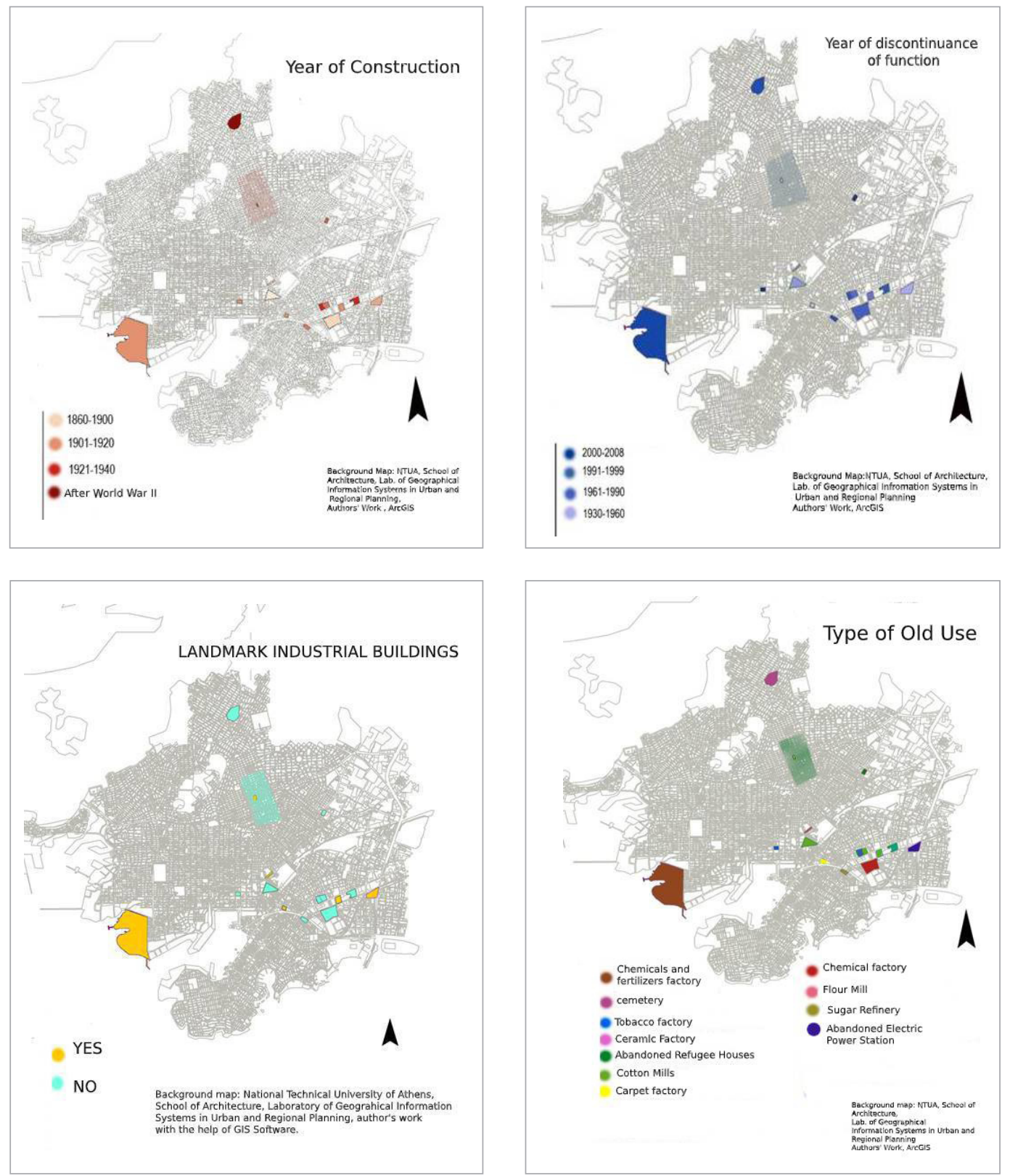
The last ten years the presence of foreign investors alters former balances. New approaches on urban and regional planning are bound to transform the identity of the wider area around the port. Because of its geopolitical relevance and position, Piraeus has attracted Chinese private investors, turning the national port into a major node for the new Silk Road (Van der Putten et.al.,2016). Recent negotiations have led to the establishment of a Chinese key station inside the port of Piraeus, linking maritime and land transport routes. This new form of cooperation orders new directions in urban planning that are going to affect the identity of brownfields in the future. However, the reuse of brownfields in Piraeus could function as a tool for sustainable urban planning, intensifying socio-spatial cohesion.

Piraeus has many different types of brownfields, varying from vacand buildings, derlict land, abandoned land and buildings (see map 8). The research has focused on the most important brownfields according to their location and the size of the area they cover. Among Piraeus' brownfields there are areas that seem to have attributes of hardcore brownfield sites. They are not only abandoned for many decades but also not incorporated into an overall urban renewal program (see map 11). It is important to mention that most of the brownfield sites belong to type $A$ and $B$, according to CABERNET classification but there are also types -C, located far from the port in the peripheral post refugee areas, as depicted in map 12. These C-types include mostly abandoned refugee houses and blocks of flats constructed during the $30 \mathrm{~s}$. One key-obstacle is the fact that there are many different stakeholders involved since property ownership varies widely. As shown in map 10, many brownfields belong to private owners, some to the Municipality of Piraeus and the peripheral Municipalities, others to the National Bank of Greece and to the Pubic Power Corporation S.A. This factor will probably temporize the redevelopment process since it is difficult to achieve consensus among multiple actors.

The absence of an overall plan for brownfield redevelopment in areas like Piraeus, has led to the implementation of case-by-case strategies. As a result a few brownfields have already been redeveloped and are now hosting new uses, mostly commercial (see map 13). The cost of redevelopment has been in most of the cases covered by private funding. The new master plan, which was the result of recent negotiations among Chinese investors and local authorities, suggested new uses for some areas around the port. These uses included among other luxury hotel, shopping mall, cruise - ship passenger stations and a floating ship repair dock. This is a typical example of the new era in terms of globalization. However, the Central Archaeological Council (KAS) reviewed proposed investments related to its jurisdiction and ordered revisions. In particular, KAS consulted that the proposed area for hosting a large cruise-ship passenger station in the south zone of the port, named Drapetsona, is not able to accommodate a large mall of $24,000 \mathrm{~m}^{2}$ as well. According to KAS this proposal exceeded the carrying capacity of the area. This decision was also associated with the fact that there are remains of the Long Walls, constructed during the $4^{\text {th }}$ century BC. This area has also archaeological findings of Themistocles' grave, as shown in map 11.

On account of all these, brownfields in Piraeus are often mixed or near archaeological sites. The lack of cartographic depiction complicates the decision making in such cases with the view not only to preserve elements of cultural heritage but also to recommend new uses. This means that the areas of archaeological interest should be digitally depicted so as to be compared with the geographical location of brownfield sites. This procedure could clarify the borders of each type of area assisting the strategic priority planning.

Based on the conducted qualitative research, local community supports the creation of an open green space at the large brownfield site of Drapetsona rather than commercial or industrial uses. Moreover, the majority of the participants expressed skepticism on the possible impact that the new land uses are bound to have. They claim that such new uses may widen the gap between upgraded and degraded areas within the bordrers of the Regional Administrative area of Piraeus.

\section{Types of Brownfields in Piraeus}


Flagship projects as the luxury hotels might initiate gentrification procedures according to the opinion of the participants. The majority of the participants stressed, though, the significant contribution of the existing brownfield sites to the possible urban regeneration of the area. Almost all of them, correlated the existence of brownfields with urban blight, mentioning the urgent need for urban renewal. However, only a few participants ( 5 women and 3 men) stated clearly that the new land uses might prove beneficial for the local community. Nevertheless, they all agreed on the fact that the new land uses around the port, should be chosen in compliance with the needs of the local community.

\section{Fig. 10, 11} and hardcore brownfield sites in Piraeus, authors' work
Property ownership

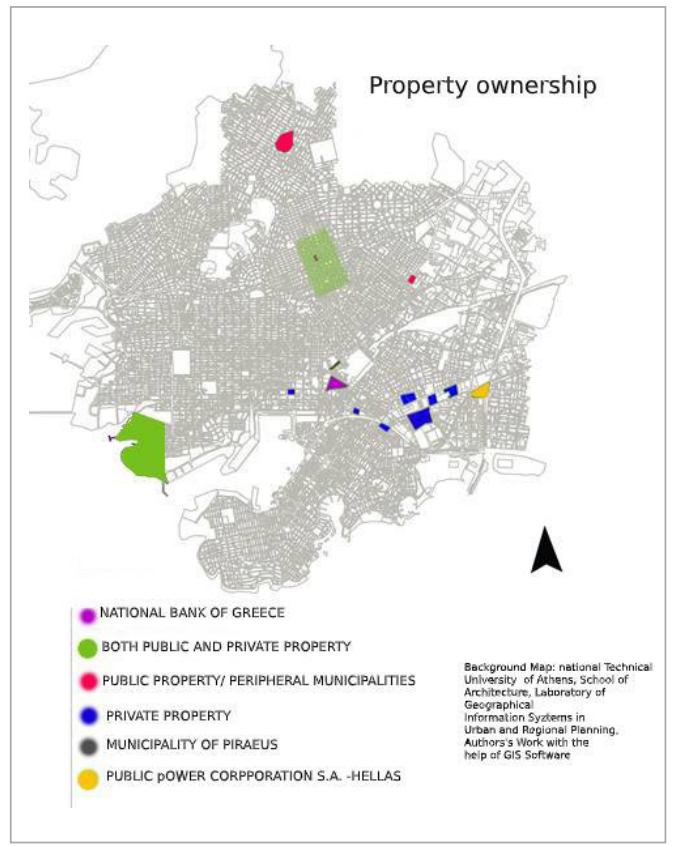

Fig. 12, 13

Piraeus brownfields according to CABERNET

classification and new uses, authors' work

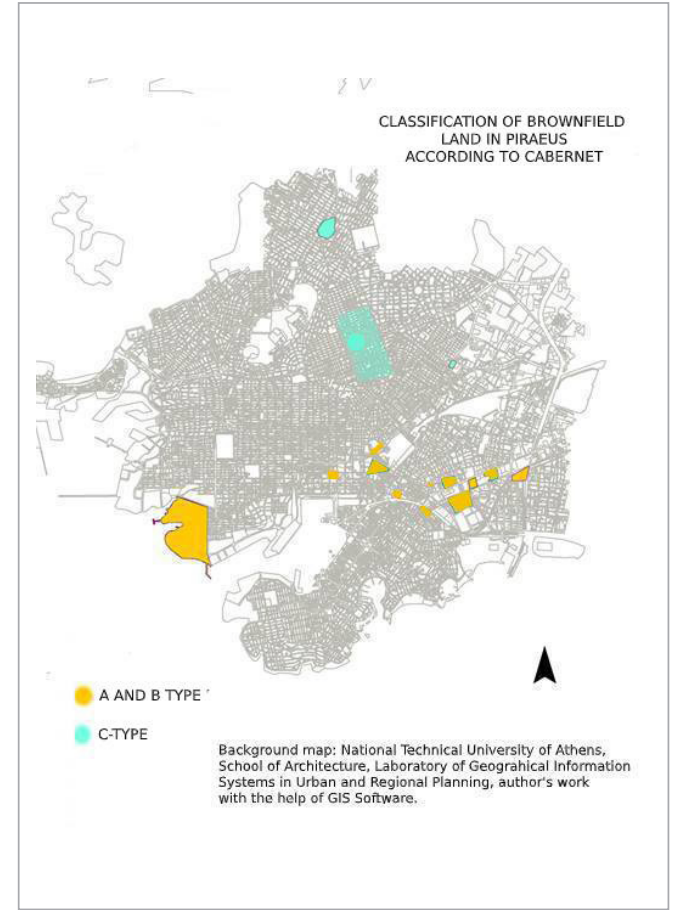

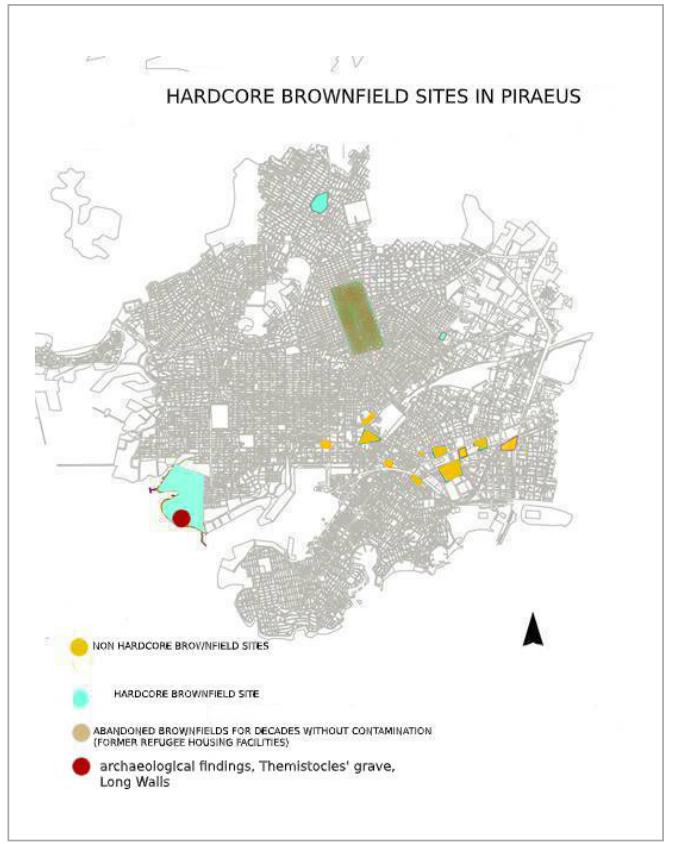

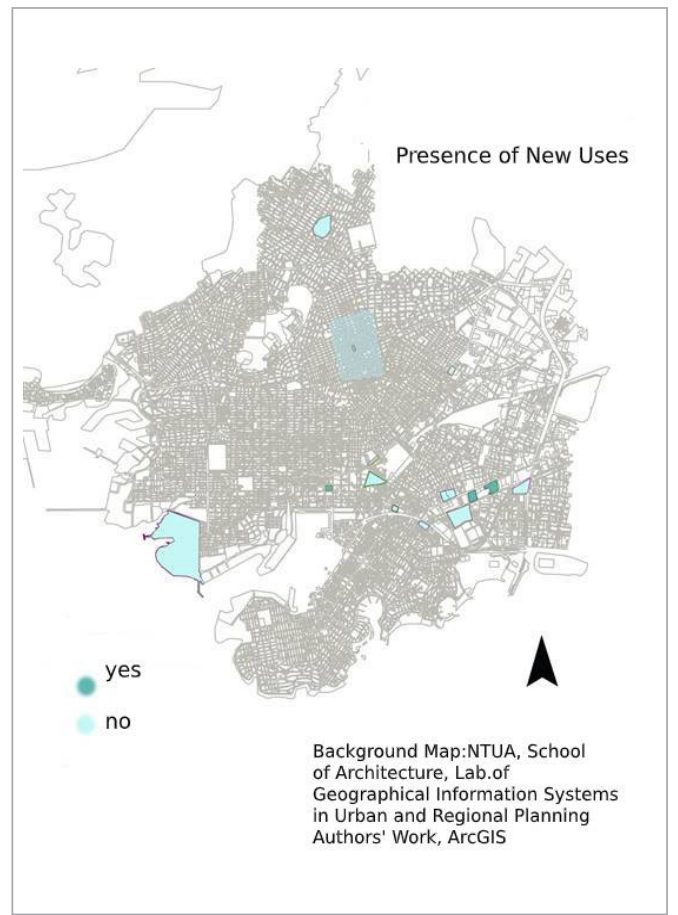


On account of all the previously mentioned, the sense of place has changed dramatically over the past decades. Traditional forms of inter-state cooperation have given way to new types of development, with innovative technologies facilitating cross-border collaborations. Apart from the old centers of global economy, strategic territories are emerging in cities that are not considered to be global. The municipality of Piraeus in Greece is a typical example of such development due to the recent opening up of the Greek economy to foreign investors. Piraeus has been the main port of Greece since the 5th century BC and is today one of the largest ports in the eastern Mediterranean Sea. Despite its contemporary geopolitical significance and all the subsequent changes on urban planning strategies, there is a lack of consistent policy concerning brownfield redevelopment. It is important to mention, that Piraeus and Greece in general, have not even reached the first stage of an international classification, (Adams and De Souza,2007), involving the encounter between cost and risk management. This means that there is plenty of room for improvement as far as brownfield management is concerned.

Expanding the discussion on brownfields beyond Piraeus and Greece, authors have attempted to illustrate the condition of brownfield recording in EU. Taking into consideration the presence or absence of digital record, authors have assesed the situation within the borders of the European Union. To fullil this purpose authors have studied a variety of sources and the available relatively recent data as the European Commission's 5th Framework Program, Key Action "The City of Tomorrow and Cultural Heritage" and "The Scale and Nature of European Brownfields" (Oliver, et.al., 2005). According to these sources there are significant discrepancies among the member states of the European Union as far as the recording of brownfield land is concerned. To update the relatively recent data, authors consulted EU's Conference Report the "Brownfield redevelopment in the EU", published in 2019. According to this last report, there are still barriers to overcome as the inadequate, conflicting or changing legal frameworks of the member states and the absence of cooperation of public authorities (DG Environment, 2019).

Based on the relatively recent available data, there are countries that have complete data bases like Germany, France and Poland (Olivier, et.al., 2005) as well as countries that do not have any type of digital data for brownfields. In the middle, one is able to find countries that lack systematic recording at national level but offer data bases for specific regions like Milan in Italy. Countries as Greece, Bulgaria, Hungary, Slovakia and Slovenia, seem to have deficiency of digital data. This issue is rather significant in areas like Piraeus where the presence of foreign investors shapes in multiple ways the prevailing urban planning strategies.

Focusing on Greece, the lack of systematic digital depiction is a major obstacle for further development. In areas like Piraeus, the deficiency of cartographic data leads to fragmentary policies. Taking into consideration the fact that these brownfields could create an urban network of multiple uses it is vital to suggest a pilot cartographic depiction, able to reveal the exact location of brownfield site, offering also information about ownership status, level of contamination and neighboring land uses. The enforcement of an urban planning program which aims at brownfield redevelopment could protect socio-economic cohesion in such areas. This could also set barriers to market driven policies that ignore citizens' needs. Another critical factor is associated with the urban blight met in the post refugee urban areas. This situation affects not only the quality of life but also the prices of land in such areas. Furthermore, the presence of archaealogical sites near brownfields complicates an already bewildering situation. A beneficial factor, though, for accelerating redevelopment by reducing rehabilitation's cost is the low level or the absence of soil contamination in most of the cases.

Undoubtedly, the issue of brownfield redevelopment is strongly associated with urban planning policies and environmental strategies. From this point of view, a sustainable brownfield policy should achieve balance among social, economic and environmental factors so as to avoid gentri-

\section{Discussion}

\section{Conclusions}


fication (Raco, 2007;Ponzini,2010 and Watson,2009). For this reason, policy makers should take into consideration all the vulnerable groups that are associated with the brownfield areas. Moreover, it is vital to keep balance between public and private sector, especially in areas like Piraeus that attract foreign investors. This balance may be expressed as a consensus among different stakeholders like the local community, the investors and the State. However, such an effort might be a complicated procedure, since different actors have different perspective on brownfield redevelopment.

Skepticism on this aspect of the issue is also found in international literature as many scholars claim stakeholder's theory to craft legal process. Using the suggestion "do the right thing" they try to address morality in urban brownfield redevelopment (Pointdexter, 1995). Taking into consideration all these, one is able to comprehend the complexity of the issue in terms of sustainability. In cases like Piraeus, pressures exercised by foreign investors are bound to shape the urban environment in ways other than public benefit. Thus, the existence of a strong national legislative framework combined with explicit urban renewal programs may function as a shield against gentrification. To conclude, city's transformations should not be implemented in ways that either harm the environment or the social cohesion (Harvey,2013). From this point of view, brownfield redevelopment could either lead to resilient compact cities or end up to severe gentrification, especialy in cases like Piraeus, where abandoned brownfield sites challenge the contemporary socio-spatial cohesion of the city.

\section{Acknowledgements}

The authors would like to thank the historic archive of Piraeus and the Municipality for their valuable support during the research.

\section{References}

Adams D., De Souza C. (2007) “ Brownfield development: A comparison of North American and British Approaches", European Urban Research Association Conference 'The Vital City ', University of Glasgow, 12 - 14 September 2007

Alker, S., Joy, V., Roberts, P., Smith, N. (2000) „The Definition of brownfield“ Journal of Environmental Planning and Management, 43, 49-69 https://doi.org/10.1080/09640560010766

Chlomoudis C. (2015) The development of the Piraeus Port Authority and COSCO, available at https://www. athenssocialatlas.gr/en/article/piraeus-and-cosco/

CPRE (2009) "Brownfield Market Signals: Greenfield housing land supply and the viability of brownfield housing development", http://www.cpre.org.uk/ reso urces/housing-and-planning/housing/

DG Environment (2019) Brownfield redevelopment in the EU, European Commision's Conference Report, Brussels 5th of April 2019, available at https:// ec.europa.eu/info/sites/info/files/brownfield_conference_report_0.pdf

Dixon, T.(2006) „Integrating sustainability into brownfield regeneration: rhetoric or reality“ Journal of Property Research, 23, 237-67 https://doi. org/10.1080/09599910600933889
Environmental Protection Agency (EPA) (2011), "Brownfields and Land Revitalization" http://epa.g ov/brownfields/

EU (2019)The EU Environmental Implementation Review 2019 Country Report - GREECE, Brussels, retrived from https://ec.europa.eu/environment/ eir/pdf/report_el_en.pdf

Harvey D. (2013) Rebel Cities: From the right to the city to the Urban revolution, Verso

Kaltsa M. (2015) Project Athens-Attica 2014, published on line at https://www.athenssocialatlas.gr/ en/article/athens-attica-2014/

HSRC (2006) "Glossary of Terms for Brownfields" New York, Hazardous Substance Research Centres.

Nebojša Stojčić, Zoran Aralica (2015) «Regional Patterns of Deindustrialization and Prospects for Reindustrialization in South and Central East European Countries», The Balkan Observatory, Working Papers, 118, December 2015, www.balkan-observatory.net

Oliver, Lee \& Ferber, Uwe \& Grimski, Detlef \& Millar, Kate \& Nathanail, Paul. (2005). The Scale and Nature of European Brownfield,

https://www.researchgate.net/publication/228789048_ The_Scale_and_Nature_of_European_Brownfield 
OECD (2017) Cruise Shipping and Urban Development. The Case of Piraeus., case specific Policy Analysis, International Transport Forum, available at https://www.itf-oecd.org/sites/default/files/docs/ cruise-shipping-urban-development-piraeus.pdf

Pentzopoulos,D., (1962) The Balkan Exchange of Minorities and Its Impact upon Greece, Mouton and Co, Paris.

Pérez A.P., Peláez Sánchez S., Van Liedekerke M. (2015) "Remediated sites and brownfields Success stories in Europe". A report of the European Information and Observation Network's National Reference Centres for Soil (Eionet NRC Soil), European Commission Institute for Environment and Sustainability, Land Resources Management

Poindexter G. ( 1995) Addressing morality in urban brownfield redevelopment: Using stakeholder theory to craft legal process, 15 Va. Envtl. L.J. 37 http:// heinonline.org/HOL/ LandingPage?handle=hein.journals/velj15\&div=9\&id=\&pa ge=

Ponzini D. (2010) "Bilbao effects and narrative defects: A critical rearrraisal of an urban rhetoric" Working Papers of the Program "Villes et Territoires”, Paris,Sciences Po. , http://blogs.sciences-p o.fr/recherche-villes/, retrived 17/6/2017

Raco M. (2007) „Building Sustainable Communities: Spatial Policy, Place Imagina-tions and labour

\section{TOUSI EVGENIA}

\section{Dr.Architect-Urban and Regional Planner, Adjunct Academic Staff}

University of West Attica, School of Applied Arts and Culture, Department of Interior Architecture

\section{Main research area}

Sustainable urban and regional planning.

\section{Address}

E-mail: etousi@uniwa.gr mobility in post-war Britain" Policy Press, Bristol. https://doi.org/10.2307/j.ctt9qgpxs

Sarigiannis G. (2000) Athens 1830-2000, Symmetria Publications, Athens (in Greek)

Sassen S. (2005) "The global city: Introducing a concept", Brown Journ al of World Affairs, winter/ spring 2005, volume xi, issue 2.

Soltaniehha M., Peric A, Schol B. (2014) The Port of Piraeus: Industrial Zone or Urban Continuity, 5th ISOCARP Congress 2014, available at https://www. academia.edu/8315681/The_Port_of_Piraeus_Industrial_Zone_or_Urban_Continuity

Van der Putten F., Montesano F.S., Van de Ven J., Van Ham P. (2016) The Geopolitical Relevance of Piraeus and China's New Silk Road for Southeast Europe and Turkey, chapter 1 Greece: Piraeus and the Maritime SilkRoad, p.11-20, The Clingendael Institute, Hague available at https://www.clingendael.org/sites/default/files/ pdfs/Report_the\%20geopolitical_relevance_of_Piraeus_and_China's_New_Silk_Road.pdf

Watson V. (2009) „The planned city sweeps the poor away. Urban Planning and 21st century urbanization" Progress in Planning 72 (2009) 151-193, Elsevier, available at http://www.wiego.org/sites/wiego. org/files/publications/files/Watson_planned.city_. sweeps.poor_.away_.pdf https://doi.org/10.1016/j. progress.2009.06.002

\section{SERRAOS KONSTANTINOS}

Professor

National Technical University of Athens, School of Architecture

\section{Main research area}

Sustainable urban and regional planning.

\section{Address}

E-mail: kserraos@arch.n tua.gr

\section{About the Authors}

